\title{
円形孔を有する集成材梁の耐力に関する研究
}

FEM による対称異等級構成集成材の割裂耐力の推定

\section{STUDY ON STRENGTH OF GLUED LAMINATED TIMBER BEAMS WITH ROUND HOLES}

Estimation of splitting strength of glued laminated timber composed of heterogeneous grade by finite element analysis

岡本滋史 ${ }^{* 1}$, 荒木康 弘 $^{* 2}$, 秋山信彦*3,

小谷竜城*4, 青木謙治*5, 稲山正弘*6

\section{Shigefumi OKAMOTO, Yasuhiro ARAKI, Nobuhiko AKIYAMA, Ryuki ODANI, Kenji AOKI and Masahiro INAYAMA}

\begin{abstract}
At present, few strength evaluation methods have been established for timber beams containing round holes but several have been proposed in Japan and overseas. However, it is not clear whether the method can be applied to glued laminated timber composed of heterogeneous material grades mainly used for beams in Japan and elsewhere. In this paper, we experimentally verify that the proposed strength evaluation method can be applied to glulams. Moreover, we verify that the strengths of glulams that also contain round holes can be estimated using finite element analysis.
\end{abstract}

Keywords : Glued laminated timber, Beam, Round hole, Splitting, Finite element method 集成材, 梁, 円形孔, 割裂, 有限要素法

\section{1.はじめに}

建築を経済的に設計する場合には、建築物の高さや階高を抑えて 天井高さを確保することが求められるが、梁せいが大きいと梁下部 に設備配管等を配置できない場合があり、梁に孔を設けて対応する 必要がある。鋼構造や鉄筋コンクリート造では、孔を設けた梁の補 強方法や耐力評価法が確立されているが、木質構造では、I ビーム の OSB 等のウェブ部分に孔を設けるものを除くと、文献 1)2)で仕 様規定として製材や集成材の円形孔を設けた梁（以下、有孔梁とす る。）の制限が記載されているが、有孔梁の耐力評価法は示されてい ない。

国外ではスウェーデンやドイツなどで有孔梁の耐力評価法が設計 規準等に定められており、文献 3)4)に詳しくまとめられている。繊 維直交方向に作用寸る引張（以下、横引張とする。）によって孔が割 裂破壞するときの耐力を算定するもので、各耐力評価法の概要は以
下の通りである。

(1) テーパー梁と仮定した耐力評価法

Fig. 1 に示寸ように孔の周りの応力分布をテーパー率 $1 / 1$ のテー パー梁とほぼ同じであると仮定し、テーパー梁の強度算定式に基づ いた耐力評価法である。

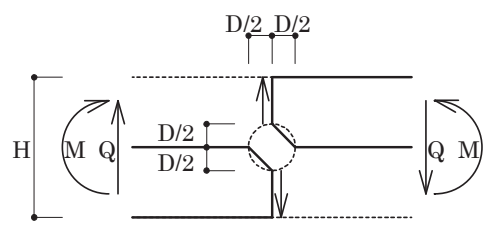

Fig.1 Tapered beam model

（2）横引張力による耐力評価法

Fig.2 に示すように $45^{\circ}$ 部分に作用する横引張力 $\mathrm{T}_{90}$ を $\left(0.5 \times \mathrm{l}_{\mathrm{t} 90}\right.$
*1 大阪市立大学大学院生活科学研究科 講師 $\cdot$ 博士 (工学

$* 2$ 国土技術政策総合研究所主任研究官・博士 (工学)

*3 国土技術政策総合研究所 研究官・博士 (農学)

*4 (株)エヌ・シー・エエ 博士 (農学)

*5 東京大学大学院農学生命科学研究科准教授・博士(農学)

*6 東京大学大学院農学生命科学研究科 教授. 博士 (工学
Lect., Grad. School of Human Life Sci., Osaka City Univ., Dr.Eng. Senior Researcher, National Institute for Land and Infrastructure Management, Dr.Eng.

Researcher, National Institute for Land and Infrastructure Management, Dr.Agr. New Constructor's Network, Dr.Agr.

Assoc. Prof., Grad. School of Agric. and Life Sci., The Univ. of Tokyo, Dr.Agr.

Prof., Grad. School of Agric. and Life Sci., The Univ. of Tokyo, Dr.Eng. 
×梁幅)で除して横引張応力度 $\sigma_{t 90}$ を算定し、それが横引張強さに到 達する時点の負担荷重を耐力とする耐力評価法である。せん断力に よって生じる横引張力は理論的に誘導され、モーメントによって生 じる横引張力は実験式である。
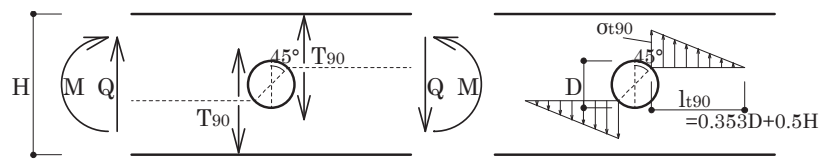

Fig.2 Tension strength perpendicular to the grain

（3）寸法効果を考慮した横引張力による耐力評価法

(2)の考え方と同様に横引張応力度が横引張強さに到達する時点 の負担荷重を耐力と寸る耐力評価法であるが、横引張応力度 $\sigma_{\mathrm{t} 90}$ は FEM を用いて誘導し、Fig. 3 に示寸 $\Omega$ の部分に応力が作用してい るとして寸法効果をワイブル最弱リンク理論による補正係数として 定めている点が異なる。

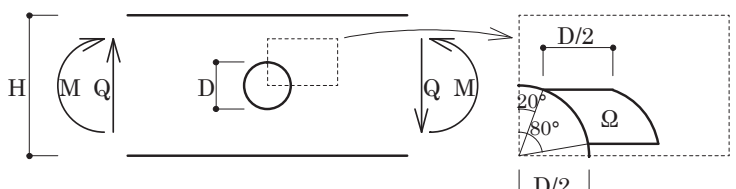

Fig.3 Large stress area

国内でも文献 5)6)で耐力評価法が提案されており、こちらも同様 に横引張によって孔が割裂破壊するときの耐力を算定するもので、 各耐力算定方法の概要は以下の通りである。

（4）モード I の破壊エネルギー $\mathrm{G}_{\mathrm{Ic}}$ を用いた耐力評価法

文献 5)では孔周りに作用する横引張力による割裂耐力を破壊エ ネルギーを用いて推定する方法を提案している。破壊エネルギーを 用いることで寸法効果も評価できていることが示されている。

（5）斜め引張による耐力評価法

文献 6)では、横引張だけではなく他の応力成分も破壊に影響して いるとして、Fig.4 に示すように孔の接線方向に作用している最大 主応力が斜め引張強度を超えないことを確認する耐力評価法を提案 している。

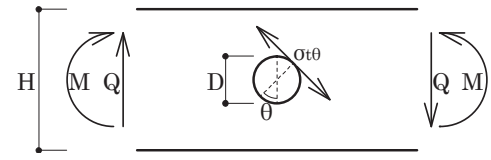

Fig.4 Estimation of splitting strength by principal stress

このように国内外で有孔梁の耐力評価法はいくつか提案されてお り、これらの耐力評価法を用いて有孔梁の割裂耐力を設計すること は可能である。しかし、(1)(2)(3)の耐力評価法のほとんどが材せいに わたって異なる等級ラミナで構成されるため材料定数を同等とみな せない対称異等級構成集成材で適用可能かが示されておらず、国内 で一般的に用いられる集成材の梁に適用できるかがわからない。ま た、(4)(5)の耐力評価法は対称異等級構成集成材で検証されているが、

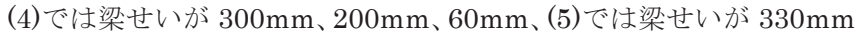
で検証されており、梁せいが大きい集成材に適用できるかがわから ない。
そこで、本研究では対称異等級構成集成材を対象として、梁せい と孔径を実験変数とした曲げせん断試験を行い、提案されている耐 力評価法が適用可能であるかを報告する。また、孔周りに作用する 応力がわかっていれば割裂耐力を精度良く推定できるかを検討する ため、FEMによる割裂耐力の推定方法の提案と検証を行った。

\section{2. 曲げせん断実験}

\section{1 実験概要}

有孔梁の耐力評価法は主に、せん断強さから算定するものと横引 張強さから算定寸るものがある。そこで、梁の樹種はせん断強さが 高く横引張強さが低いカラマツとせん断強さが低く横引張強さが高 いオウシュウアカマツの 2 種類とし、強度等級は同じ対称異等級構 成集成材 E105-F300 とした。試験体及び仕様を Fig.5 に示す。試験 体を曲げ破壊させることなく孔の割裂により破壊させるための形状 を(1)〜(5)の耐力評価法で試設計し、 $\mathrm{a} ， \mathrm{~b} ， \mathrm{~d}$ の寸法を定めた。孔は 加力点からの距離が短い支点側の梁せいの中央に設けた。孔径は基 本的に梁せいに対する比率で 4/5〜1/5 の大きさと梁せいに関わら ず $30 \mathrm{~mm}$ とする 5 種類とした。比較のため孔を設けないものを用 意した。150mm、300 mm、450mm の 3 種類とし、これに加えてオ ウシュウアカマツのみ $750 \mathrm{~mm}$ を用意した。オウシュウアカマツの 梁せい $750 \mathrm{~mm}$ の孔径は $1 / 3$ のみとした。試験体は仕様によって 3 体又は 2 体ずつである。

加力は 1 方向単調載荷とし、変位は加力点位置及び支点位置に変 位計を設置して加力点位置の梁のたわみを計測した。

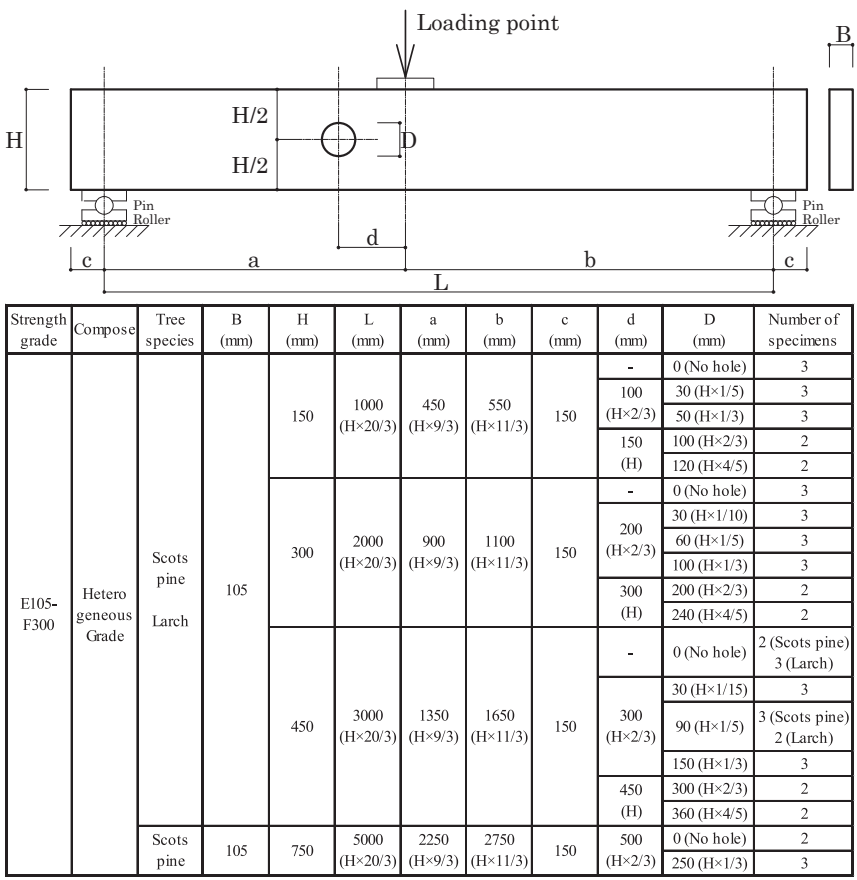

Fig.5 Test specimens and specifications

\section{2 実験結果}

孔を設けていないすべての試験体、梁せい $450 \mathrm{~mm}$ に $30 \mathrm{~mm}$ の孔 を設けたすべての試験体、梁せい $300 \mathrm{~mm}$ に $30 \mathrm{~mm}$ の孔を設けたオ ウシュウアカマツ試験体 1 体が孔に亀裂が生じずに曲げ破壊したが、 その他の試験体では Photo1 のように孔に亀裂が生じて破壊した。 孔に亀裂が生じた試験体は、多くの場合、最初に加力側上部に短い 
亀裂が生じ、その後亀裂がある程度の長さまで進展した後に支点側 下部に亀裂が生じ、その亀裂が木口まで進展して耐力が低下した。 一方で、このように段階的に亀裂が生じて破壊せずに、すべての亀 裂が同時に生じて破壊する試験体も見られた。

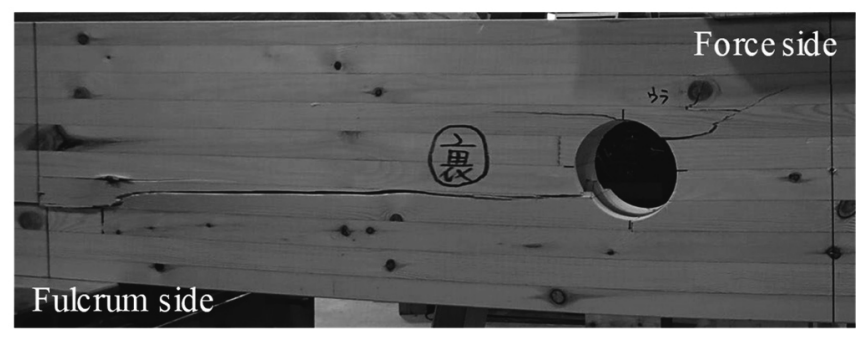

Photo1 Typical destruction

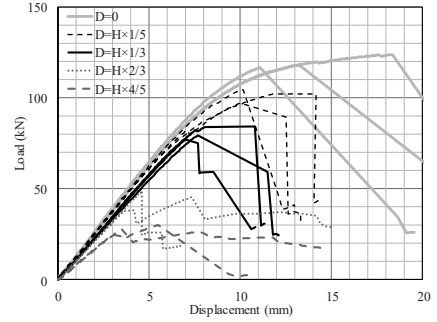

$\mathrm{H}=150 \mathrm{~mm}$, Scots pine

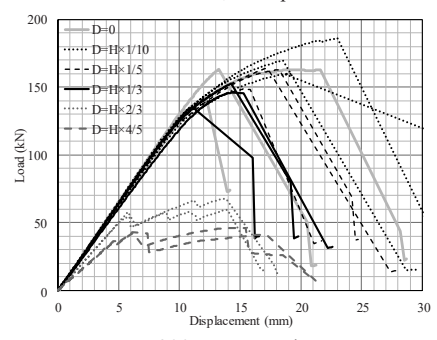

$\mathrm{H}=300 \mathrm{~mm}$, Scots pine

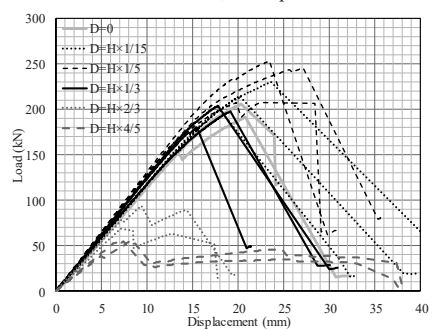

$\mathrm{H}=450 \mathrm{~mm}$, Scots pine

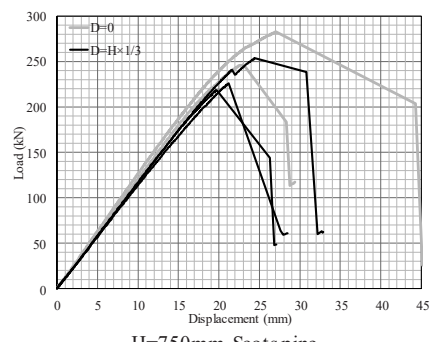

$\mathrm{H}=750 \mathrm{~mm}$, Scots pine

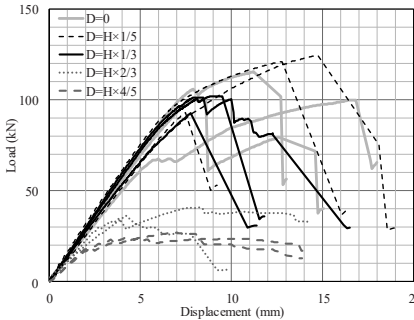

$\mathrm{H}=150 \mathrm{~mm}$, Larch

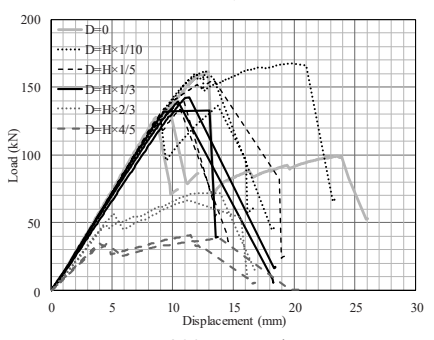

$\mathrm{H}=300 \mathrm{~mm}$, Larch

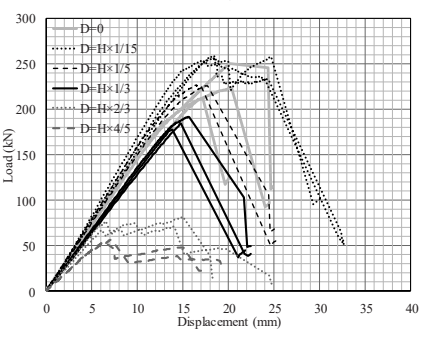

$\mathrm{H}=450 \mathrm{~mm}$, Larch
Fig.6 Load displacement relations at the loading point

荷重一変位関係を Fig.6 に示す。縦軸は加力点の荷重で、横軸は 加力点の変位である。すべて曲げ破壊した梁せい $450 \mathrm{~mm}$ で孔径が $30 \mathrm{~mm}$ の試験体を除くと、孔が大きくなるにつれて耐力が低下寸る 傾向が見られたが、孔径が梁せいの $1 / 5$ 以下では曲げ破壊した試験 体と同程度の耐力となり、孔径が梁せいの $1 / 3$ であっても同程度か
耐力が若干低い程度の結果となった。文献 3)には 2002 年の Eurocode 5 最終案の内容が記載されており、「孔径が $50 \mathrm{~mm}$ 未満で 梁せいの 0.1 未満の場合は無視できる」とある。曲げ破壊した試験 体は孔径が $30 \mathrm{~mm}$ で梁せいの $1 / 15$ と $1 / 10$ の一部の試験体であり、 孔を無視できるとされているものが、耐力低下もなければ Eurocode の適用範囲に符合する結果となっていると言える。

孔に亀裂が生じて破壊したオウシュウアカマツとカラマツの最大 耐力を比較してみると、梁せい $150 \mathrm{~mm}$ では $\mathrm{D}=\mathrm{H} \times 2 / 3$ 以上の場合 はオウシュウアカマツの方が高く、梁せい $300 \mathrm{~mm}$ では $\mathrm{D}=\mathrm{H} \times 2 / 3$ 以外はオウシュウアカマツの方が高く、梁せい $450 \mathrm{~mm}$ では $\mathrm{D}=\mathrm{H} \times$ 2/3 以下ではオウシュウアカマツの方が高い結果となった。

\section{3 初期クラック荷重}

初期クラックが表面に全て現れて目視で確認できるわけではない ため、ここでは目視で確認できた試験体から、初期クラックの出現 寸る変位を評価し、その評価基準変位から全ての試験体について初 期クラック荷重を定義することとした。曲げ破壊した試験体は除き、 孔に亀裂が生じて破壊に至った試験体は 67 体で、耐力が低下せず に加力側上部の短い亀裂を目視で確認できた試験体が 36 体である。 荷重一変位関係の 0.1Pmax と $0.4 \mathrm{Pmax}$ を結ぶ直線の傾きを剛性と して、その直線を $0.1 \mathrm{~mm}$ ずつオフセットして、荷重一変位関係と の交点の荷重を求め、その荷重が目視で亀裂が確認できたときの荷 重と一致するときの変位のオフセット值を評価した。亀裂発生時の 変位のオフセット值の出現率を Fig.7 に示す。変位が $0.2 \mathrm{~mm}$ オフ セットした時で $33 \% 、 0.2 \mathrm{~mm}$ 以上では $97 \%$ となった。よって、す べての亀裂が同時に生じた試験体や表面に亀裂が生じずに目視で確

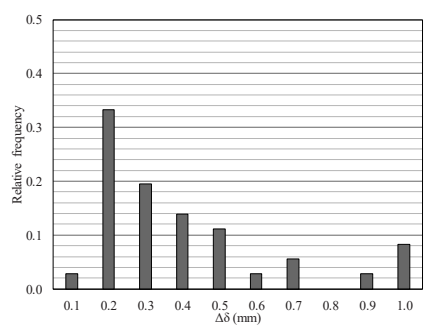

Fig.7 Initial crack offset displacement

Table1 Maximum load and initial crack load

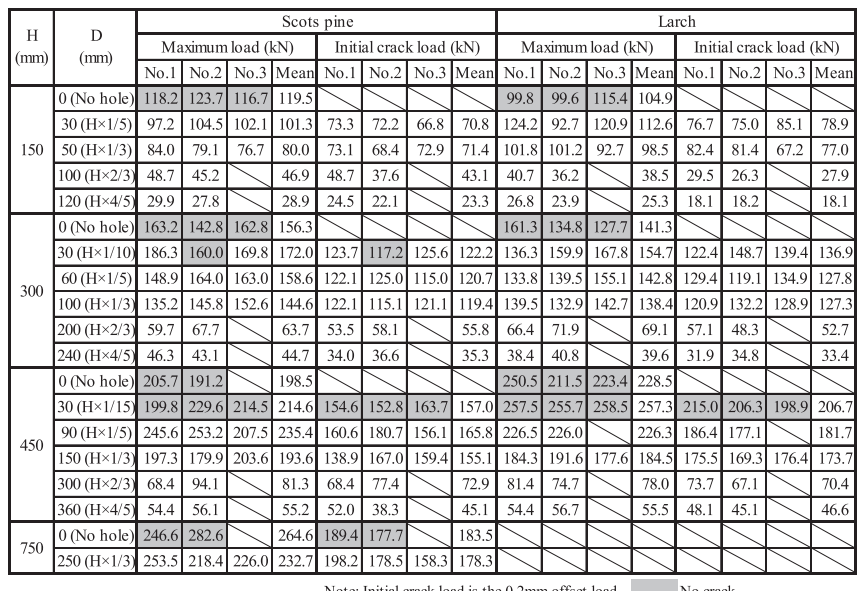

Note; Initial crack load is the $0.2 \mathrm{~mm}$ offset load, $\quad$ No crack

認できなかった試験体を含め、ここでは変位が $0.2 \mathrm{~mm}$ オフセット 
した時の荷重を初期クラック荷重として定義する。すべての試験体 の最大荷重と初期クラック荷重は Table1 の通りである。

\section{3. 材料特性}

4 章と 5 章で必要な材料特性（せん断強さ、繊維方向引張強さ、 横引張強さ、モード I の破壊エネルギー）を調べるための要素実験 を行った。要素実験を無欠点の小試験片で行うと材料強度が高くな る可能性があるため、材幅は試験装置の都合を除き基本的に曲げせ ん断試験体と同じ $105 \mathrm{~mm}$ とした。また、孔が大きいものを除きほ とんどの試験体が L80 の内層ラミナの部分で亀裂が生じて破壊し ているため、オウシュウアカマツとカラマツの L 80 の材料特性のみ を調べることにした。

せん断強さを調べる試験は、JIS Z 2101 に従ったせん断面が $30 \mathrm{~mm} \times 30 \mathrm{~mm}$ のい寸型せん断試験とし、破壊した位置の強度を知 るために曲げせん断実験に用いた試験体から Fig. 8 のように切り出 して各樹種で 20 体の実験を行った。文献 7)によるとせん断面の幅 が大きくなってもせん断強さは低下しないことが示されており、ま た試験装置の都合で $105 \mathrm{~mm}$ 幅のせん断試験を行うことが難しかっ たため、せん断試験のみ材幅が $30 \mathrm{~mm}$ のものとした。

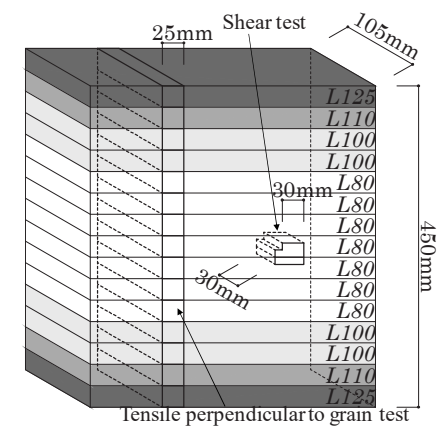

Fig.8 Specimens cut from full-scale test

繊維方向引張強さを調べる試験は、曲げせん断実験に用いた試験 体を製造した工場で同仕様の L80 のラミナから断面が $105 \mathrm{~mm} \times$ $25 \mathrm{~mm}$ で長さが $1000 \mathrm{~mm}$ の試験片を作製した。引張試験は、材端 を $200 \mathrm{~mm}$ ずつチャックで固定し、一方向の単調加力試験とした。 試験体にはくびれを設けずに断面を一様としたため、材端のチャッ ク部分で破壊したものは試験体数にはカウントせずに除外し、各樹 種で 20 体の実験を行った。

横引張強さを調べる試験は、文献 8)によると JIS Z 2101 に従っ た試験では試験片中央で破壞しないことが多いと報告されており、 曲げ試験によって横引張り強さを求める試験方法が提案されている。 そこで、本研究でも Fig.9 に示す曲げ試験により横引張強さを求め ることにした。曲げ試験によって横引張り強さを求める試験方法は ISO 13910 でも示されており、こちらでは最大曲げモーメント $\mathrm{M}_{\max }$ を断面係数 Z で除した平面保持を仮定した最大曲げ応力度に最弱リ ンク理論に基づく低減係数を乗じている。

このことから、寸法効果を考慮する必要があることがうかがえ、 材せいに応じて $\mathrm{M}_{\max } / \mathrm{Z}$ から求められる横引張強さが変化すること が想定できる。コンクリートの曲げ強度の寸法効果に関しては、文 献 9)の 4.2 .2 で仮想ひびわれモデルを用いた FEM による解析結果
が報告されており、材せいが大きくなるにつれて $\mathrm{M}_{\max } / \mathrm{Z}$ で求めら れる曲げ強さが低下し、引張強さに漸近することが示されている。 これは引張縁が塑性化したあとの引張軟化特性の影響で、平面保持 の仮定が成り立っていないためである。コンクリートの引張軟化特 性は文献 9)などの様々な文献に記載されており、木材の横引張の引 張軟化特性は文献 10)などに記載されているが、コンクリートと木 材の横引張を比較するとおおよそ似たような引張軟化特性となって いる。そこで、木材の横引張もコンクリートと同様の結果になると の予想のもと、寸法効果の影響を受けない範囲で直接的に横引張強 さを調べることができる適切な材せい $\mathrm{H}$ を検討することを目的に、 事前検討として、ラミナをすべてオウシュウアカマツ L 80 とした集 成材で材せい H を変数とした Fig.9 の実験を行った。試験体仕様と その結果を Fig10 に示す。実験結果から材せいが $150 \mathrm{~mm}$ と $300 \mathrm{~mm}$ では $\mathrm{M}_{\max } / \mathrm{Z}$ で求められる曲げ強さがほぼ等しい值となり横引張強 さに近い值が求められていると考えられる。そこで、横引張強さを 求める試験体は材幅 $\mathrm{B}=105 \mathrm{~mm}$ 、材せい $\mathrm{H}=150 \mathrm{~mm}$ 、支点間距離 $\mathrm{L}=500 \mathrm{~mm}$ の曲げ試験とし、ラミナをすべてオウシュウアカマツ L80 としたものが 6 体、ラミナをすべてカラマツ L80 としたものが 3 体の実験を行った。

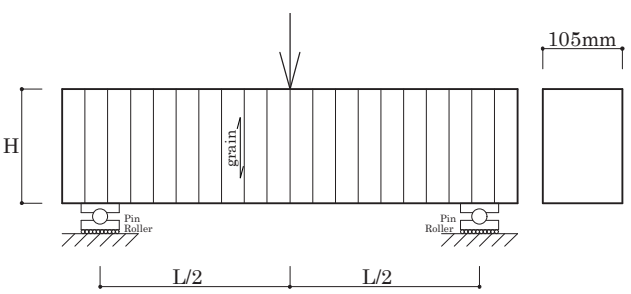

Fig.9 Test for tension strength perpendicular to grain
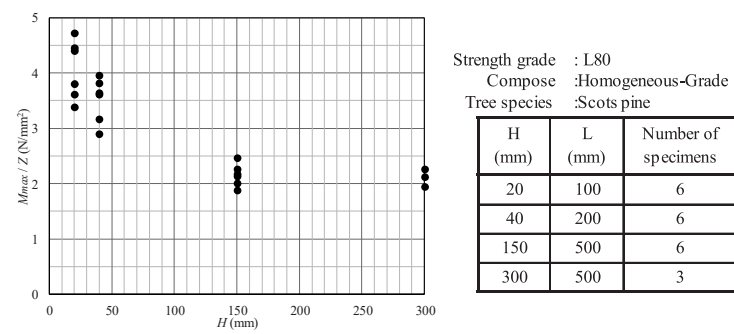

Fig.10 Test results for tension strength perpendicular to grain

モードI の破壊エネルギーG $\mathrm{G}_{\mathrm{Ic}}$ は、文献 11) と同様の SENB の試験 方法とした。 $\mathrm{G}_{\mathrm{Ic}}$ の算定式はここでは割愛する。試験体は切り欠き 部分と支点部分の木材を接着するものではなく、ラミナをすべて L80 とした集成材から切り出した Fig.11 に示寸試験体で、オウシュ ウアカマツは 10 体、カラマツは 6 体の実験を行った。

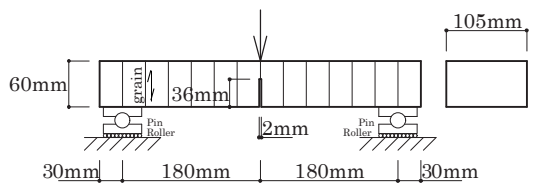

Fig.11 Schematic diagram of single-edge-notched bending (SENB) test

各要素実験から得られた材料特性を Table 2 に示す。横引張強さ は、曲げせん断実験に用いた試験体から Fig.8のように切り出して、 
材端を $100 \mathrm{~mm}$ ずつチャックで固定して引張った試験も行ったので その結果も参考值として示している。

Table2 Element test results

\begin{tabular}{|c|c|c|c|c|c|c|}
\hline & & Tree species & AVE. & MAX. & MIN. & C.V. \\
\hline \multirow{2}{*}{ Shear strength parallel to the grain } & \multirow{2}{*}{$\mathrm{F}_{\mathrm{s}}\left(\mathrm{N} / \mathrm{mm}^{2}\right)$} & Scots pine & 7.17 & 8.38 & 6.12 & 0.079 \\
\hline & & Larch & 8.72 & 10.09 & 7.52 & 0.079 \\
\hline \multirow{2}{*}{ Tension strength parallel to the grain } & \multirow{2}{*}{$\mathrm{F}_{\mathrm{t}}\left(\mathrm{N} / \mathrm{mm}^{2}\right)$} & Scots pine & 22.30 & 28.58 & 16.23 & 0.168 \\
\hline & & Larch & 20.31 & 26.16 & 16.34 & 0.126 \\
\hline \multirow{2}{*}{$\begin{array}{l}\text { Tension strength perpendicular to } \\
\text { the grain }\end{array}$} & \multirow{2}{*}{$\mathrm{F}_{\mathrm{t} 90}\left(\mathrm{~N} / \mathrm{mm}^{2}\right)$} & Scots pine & 2.15 & 2.46 & 1.88 & 0.094 \\
\hline & & Larch & 1.98 & 2.01 & 1.94 & 0.019 \\
\hline \multirow{2}{*}{$\begin{array}{l}\text { Tension strength perpendicular to } \\
\text { the grain (Reference values) * }\end{array}$} & \multirow{2}{*}{$F_{t 90}\left(\mathrm{~N} / \mathrm{mm}^{2}\right)$} & Scots pine & 1.40 & 2.23 & 0.75 & 0.288 \\
\hline & & Larch & 1.11 & 1.82 & 0.45 & 0.397 \\
\hline \multirow{2}{*}{ Fracture energy (Mode I) } & \multirow{2}{*}{$\mathrm{G}_{\mathrm{Ic}}\left(\mathrm{N} \cdot \mathrm{m} / \mathrm{m}^{2}\right)$} & Scots pine & 375 & 475 & 243 & 0.238 \\
\hline & & Larch & 280 & 314 & 223 & 0.127 \\
\hline
\end{tabular}

\section{4. 既往の耐力評価法による割裂耐力の推定}

Table2 の平均値を用いて 1 章の (1) 〜 (5) の耐力算定方法で 2 章の 曲げせん断実験の耐力を求めた。実験值と計算值の比較を Fig. 12 に 示す。計算值は、 $\mathrm{H}=38 \mathrm{~mm}$ から $75 \mathrm{~mm}$ 毎に計算してその計算結果 を直線で結んだものになる。(1)〜 (4)では最大耐力よりも過大に評価 され、(5)では初期クラック時の耐力よりも安全側に評価する結果と なった。実験值では、梁せいが大きくなるにつれて耐力が増加しに くくなっているが、寸法効果を考慮している(3)と(4)でも同じような 傾向が見られ、耐力算定には寸法効果を適切に評価する必要がある ことがわかった。

(1) （3）の耐力算定方法は、文献 3)4)でも様々な研究で行われた有 孔梁の曲げせん断実験の初期クラック時の耐力と比較がされており、 こちらでは概䇏計算值が安全側に評価できていることが示されてい る。計算に用いられた材料強度は実験值ではない設計に用いられる 值であり、(1)では $\mathrm{F}_{\mathrm{s}}=3.8 \mathrm{~N} / \mathrm{mm}^{2} 、(2)(3)$ では $\mathrm{F}_{\mathrm{t} 90}=0.5 \mathrm{~N} / \mathrm{mm}^{2}$ であ る。これらの值を用いた計算值も Fig.12 に示しているが、(1)は精 度良く初期クラック時の耐力を推定しているが、(2)(3)はかなり安全 側の推定結果となった。オウシュウアカマツとカラマツでは基準強 度が異なり、海外の基準強度とも異なるため、これらの設計式で安 全側に評価するためには適切に低減された設計強度を用いる必要が ある。(4)の耐力算定方法は、文献 5)で初期クラック時の耐力の大き な傾向は捉えられているものの安全側の評価にはなっていないとさ れているので、今回の検証も概ね同じような結果が得られている。 (5)の耐力算定方法は、文献 6)で小試験片の要素試験結果から得られ た材料強度を用いて、最大耐力を安全側に評価できると検証されて いるが、本研究とは材料強度を得るための試験方法が異なるため、 かなり過小に評価される結果となった。

これらのことから、耐力算定方法によって材料強度の定め方が異 なるため、設計に用いる場合には耐力算定方法に応じて適切に設定 された設計強度を用いる必要があることが分かった。

\section{FEM による割裂耐力の推定}

木材の横引張の引張軟化特性の影響で、材せいによって曲げ強さ が異なることを Fig10 で示した。これは応力勾配がある場合の寸法 効果として文献 12)では、材料の一点における応力状態ではなく、 一定長さの平均応力として考えることが示されている。有孔梁でも 平均応力を用いた割裂耐力の推定方法が文献 13)で提案されており、 Fig.13 に示すように破壊する位置の横引張とせん断の応力度分布
をFEM により求め、潜在的な破壊領域の一定長さ $\mathrm{ams}$ の平均忘力
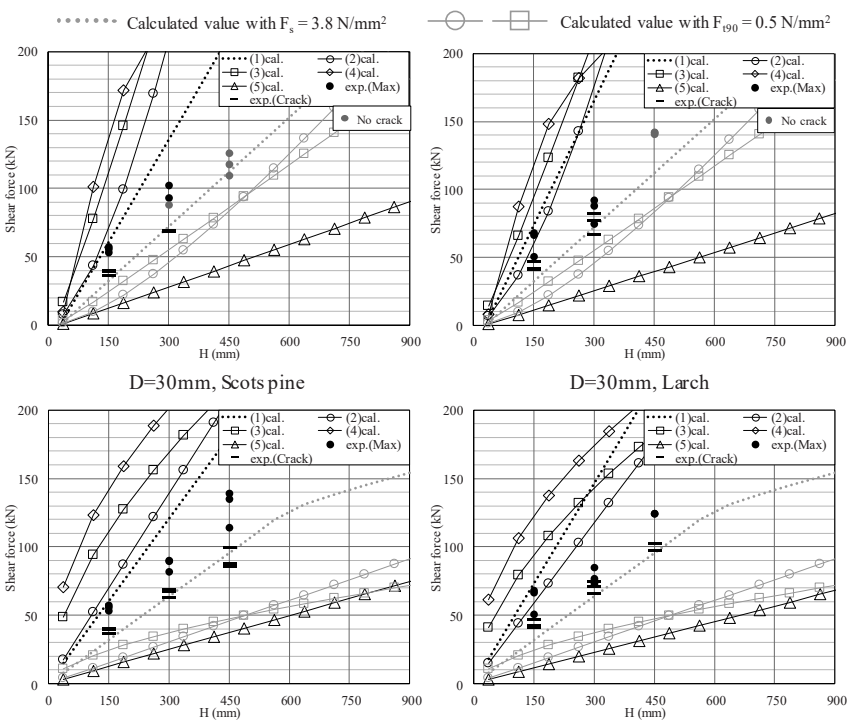

$\mathrm{D}=\mathrm{H} \times 1 / 5$, Scots pine
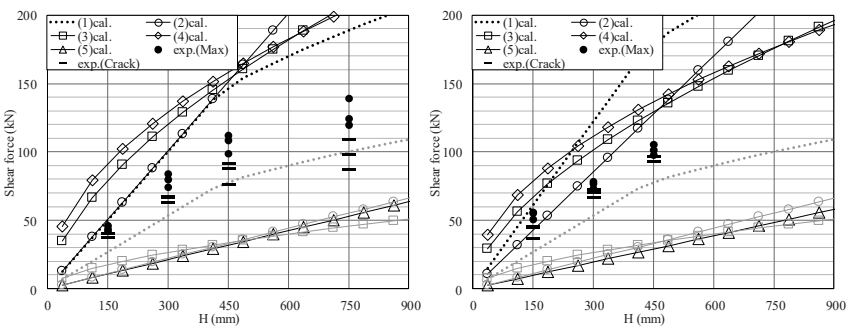

$\mathrm{D}=\mathrm{H} \times 1 / 3$, Scots pin
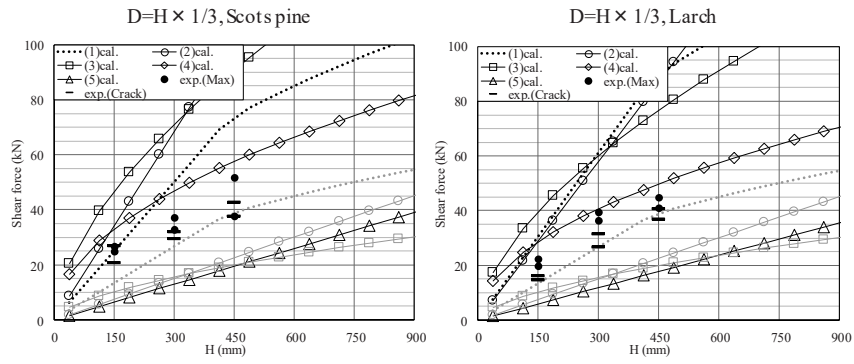

$\mathrm{D}=\mathrm{H} \times 2 / 3$, Scots pin
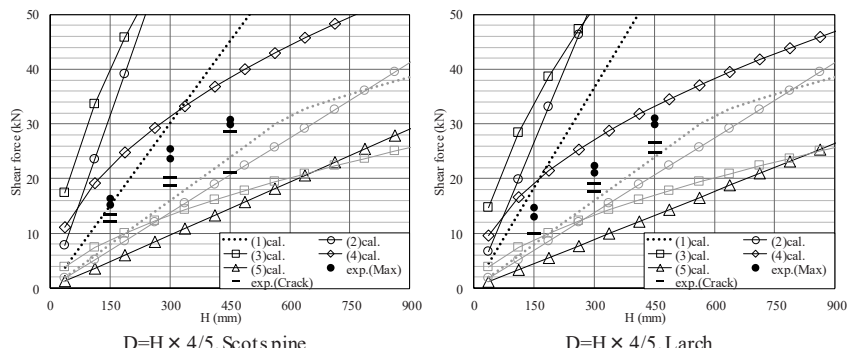

Fig.12 Experimental and calculated values

を用いて割裂耐力を推定するものである。しかし、この方法は孔径 が大きい場合には精度良く推定できるが、孔径が小さい場合は割裂 耐力を高めに推定するとい う問題点があると文献 13)で 指摘されている。そこで、こ の問題点の解決方法を提案 し、梁せいや孔径が小さいも のから大きいものまで対応 可能な FEMによる割裂耐力

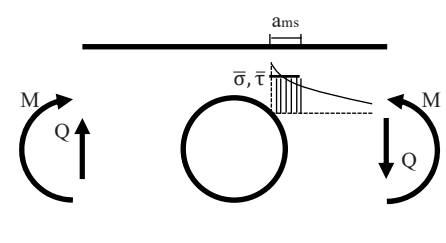

Fig.13 Mean stress 
の推定方法の提案及び検証を行う。

\section{1 割裂破壊する位置の特定}

割裂破壊寸る位置は、有孔梁の孔周りに作用する横引張応力度が 最大となる位置であると仮定する。孔周りに作用する応力度は ANSYS 14.5 を用いて 2 次元の有限要素解析により求めた。解析モ デルは、Fig.14のように孔の部分が曲げせん断実験と同様の応力状 態となるように設定した。木材を 4 節点平面要素とし、要素分割は 1 辺を $10 \mathrm{~mm}$ 、孔周りは節点が 1 度以下の配置になるように $10 \mathrm{~mm}$ 程度の範囲のみ細かく分割した。要素の 1 辺を $1 / 2$ とした場合の解 析結果と比較しても Fig.16, Fig.17 の応力度が 1\%以下の誤差であ ったため、Fig.14の解析モデルでも最適の解が得られていると判断 した。また、実験では孔周りの応力状態に影響を与えるような Fig.3 にあるような載荷板を設けているが、載荷板と両端の支点を考慮し た Fig.14 と同じメッシュサイズの解析を行ったところ、割裂破壊す る繊維直交方向の引張応力が作用する部分は、応力が最大のところ でも $5 \%$ 程度の誤差であったため、Fig.14 の解析モデルでも実験と の適合性を調べることができると判断した。曲げせん断実験に用い た梁は対称異等級構成集成材 E105-F300 であるので、要素の材料 定数はラミナ毎に定めた。ラミナは厚さ $30 \mathrm{~mm}$ として集成材の日本 農林規格に基づいて配置した。要素の材料定数は、繊維方向のヤン グ係数 $\mathrm{E}_{\mathrm{x}}$ を集成材の日本農林規格に示されているラミナの曲げヤ ング係数とし、繊維直交方向のヤング係数 $\mathrm{E}_{\mathrm{y}}$ 、せん断弾性係数 $\mathrm{G}$ 、 ポアソン比 $\mathrm{v}_{\mathrm{xy}}$ を文献 14)15)を参考にして、 $\mathrm{G}=\mathrm{E}_{\mathrm{x}} / 15 、 \mathrm{v}_{\mathrm{xy}}=0.4$ と定めた。 $\mathrm{E}_{\mathrm{x}} / \mathrm{E}_{\mathrm{y}}$ は木質構造の書籍によって 25 や 50 などととされ ているが、3.の繊維方向引張強さを求めた試験と参考值として横 引張強さを求めた Fig.8 の試験で得られたヤング係数を比較した結 果（Fig.15）、概ね $\mathrm{E}_{\mathrm{x}} / \mathrm{E}_{\mathrm{y}}=1 / 25$ となったため、 $\mathrm{E}_{\mathrm{y}}=\mathrm{E}_{\mathrm{x}} / 25$ と定め た。解析は孔が割裂破壊した仕様のみ行った。

解析から得られた孔周りに作用寸る横引張応力度 $\sigma$ を Fig.16 に 示す。oは孔に作用するせん断力 $\mathrm{Q}(\mathrm{N})=$ 梁幅 $\mathrm{B}(\mathrm{mm}) \times$ 梁せい $\mathrm{H}(\mathrm{mm}) \times$ 単位せん断応力度 $\tau_{1}=1\left(\mathrm{~N} / \mathrm{mm}^{2}\right)$ としたときの值である。解析結果か ら、対称異等級構成集成材であっても作用寸るせん断力が $\mathrm{Q}=\mathrm{BH \tau} \tau_{1}$ で、孔径比 $\mathrm{D} / \mathrm{H}$ が同じ場合は、。の分布がほぼ同じになることがわ かった。のの最大值は、 $\mathrm{D}=\mathrm{H} \times 4 / 5$ では $\theta=40^{\circ}$ 、その他はすべて $\theta=45^{\circ}$ であり、この位置から繊維方向（X 方向）に割裂破壊すると仮定す る。これは、曲げせん断実験で最初に亀裂が発生した位置と概ね 一 致する。また、すべてのラミナのヤング係数を $\mathrm{E}_{\mathrm{x}}=10500 \mathrm{~N} / \mathrm{mm}^{2}$ と した解析も行った。Fig. 16 の $\mathrm{D}=\mathrm{H} \times 1 / 3$ のみ $\mathrm{H}=450 \mathrm{~mm}$ の同一等

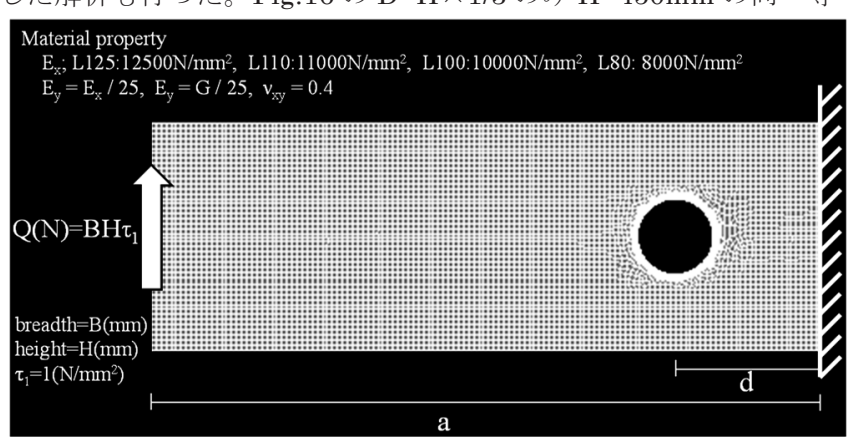

Fig.14 Analysis model

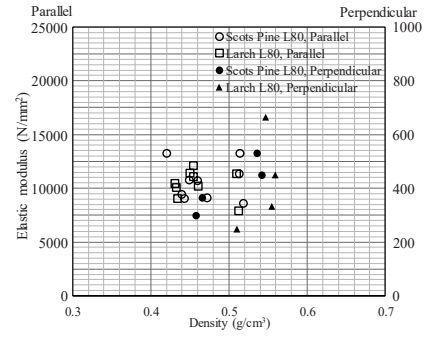

Fig.15 Modulus of elasticity parallel and perpendicular to grain

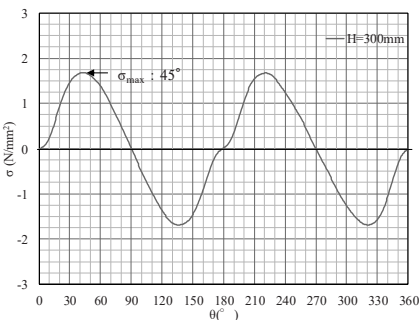

$\mathrm{D}=\mathrm{H} \times 1 / 10$

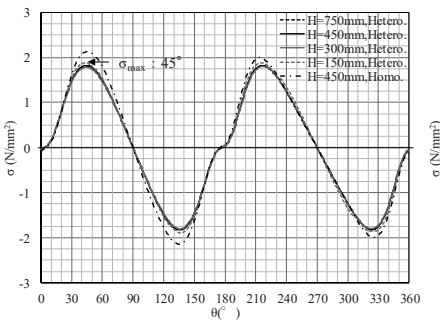

$\mathrm{D}=\mathrm{H} \times 1 / 3$

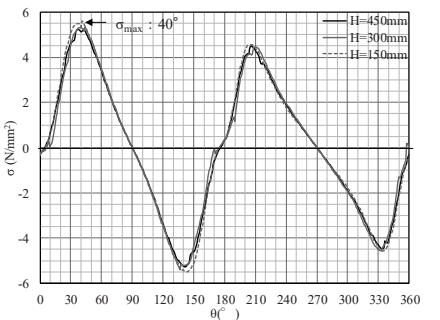

$\mathrm{D}=\mathrm{H} \times 4 / 5$

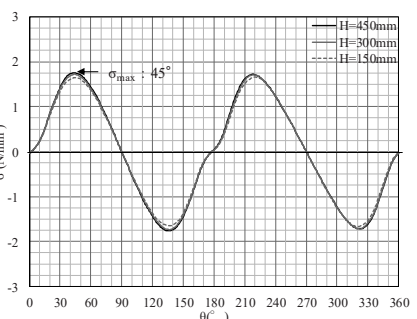

$\mathrm{D}=\mathrm{H} \times 1 / 5$

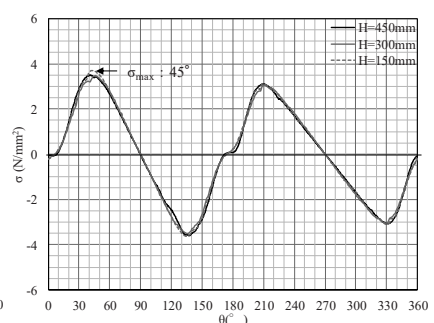

$\mathrm{D}=\mathrm{H} \times 2 / 3$

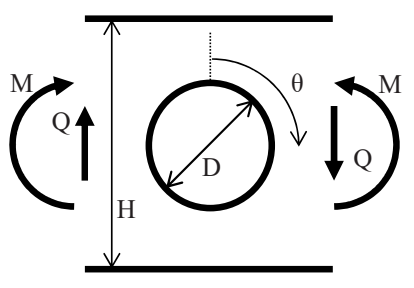

Fig.16 Tension stress perpendicular to grain around the hole
級構成の解析結果（H=450mm Homo.）を示しているが、。の最大 值は対称異等級構成の方が 0.85 程度低い結果となった。対称異等級 構成と同一等級構成の構造性能の違いについては次報で詳しく報告 する。

\section{2 割裂破壊位置の応力度分布と平均応力度}

$\mathrm{D}=\mathrm{H} \times 1 / 3$ の割裂破壊すると仮定した位置の横引張とせん断の応 力度分布を Fig.17 に示す。応力度は Fig.14の解析で得られたもの で、孔周りの割裂破壊する位置を $x=0$ として、横軸を $x / \mathrm{D}$ 、縦軸を Fig.16 と同様にせん断力が $\mathrm{Q}=\mathrm{B} \times \mathrm{H} \times \tau_{1}$ 作用したときの応力度とし ている。また、孔周りは非常に細かく要素を分割しているため、解 析結果は代表的な位置の值のみとしている。解析結果から、横軸を $x / \mathrm{D}$ とすると梁せい $\mathrm{H}$ が異なってもほぼ同様の応力度分布となるこ とがわかる。また、 $\mathrm{H}=450 \mathrm{~mm} の 6$ 次の多項式近似曲線を示してい るが、近似曲線で数式化できる応力度分布であることもわかった。 そこで、他の仕様についても解析結果から近似曲線を求めた。割裂 
破壊すると仮定した位置の横引張とせん断の応力度分布の近似曲線 を Fig.18 に示寸。 $\mathrm{D}=\mathrm{H} \times 1 / 10$ のみ $\mathrm{H}=300 \mathrm{~mm}$ の解析結果から、そ の他はすべて $\mathrm{H}=450 \mathrm{~mm}$ の解析結果からで、 $\mathrm{D}=\mathrm{H} \times 4 / 5$ と $\mathrm{D}=\mathrm{H} \times$ $2 / 3$ は $x / \mathrm{D}=0.5$ まで、その他は $x / \mathrm{D}=1$ までの解析結果から得られた 近似曲線である。こちらも孔周りの応力度分布と同様に、 $\mathrm{D}=\mathrm{H} \times 1 / 3$ 以下は孔径比が異なっても横引張、せん断共に応力度分布がほぼ同 じとなった。そして、平均応力度であるが Fig.18の各項の係数を用 いて、式(1)で長さ $\mathrm{ams} / \mathrm{D}$ の平均応力度を求めることができる。
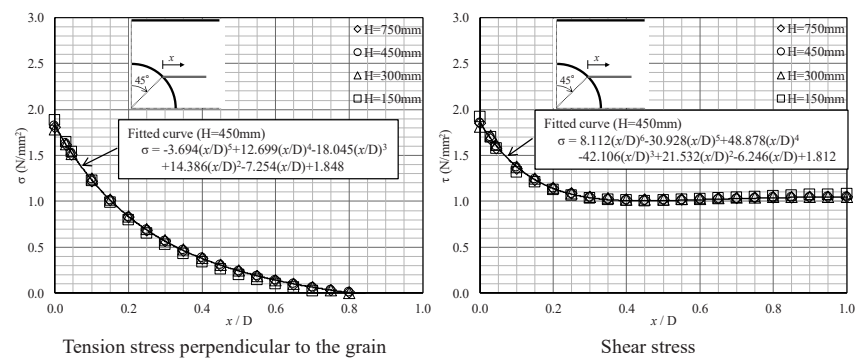

Fig.17 Stress at split fracture location $(D=\mathrm{H} \times 1 / 3)$
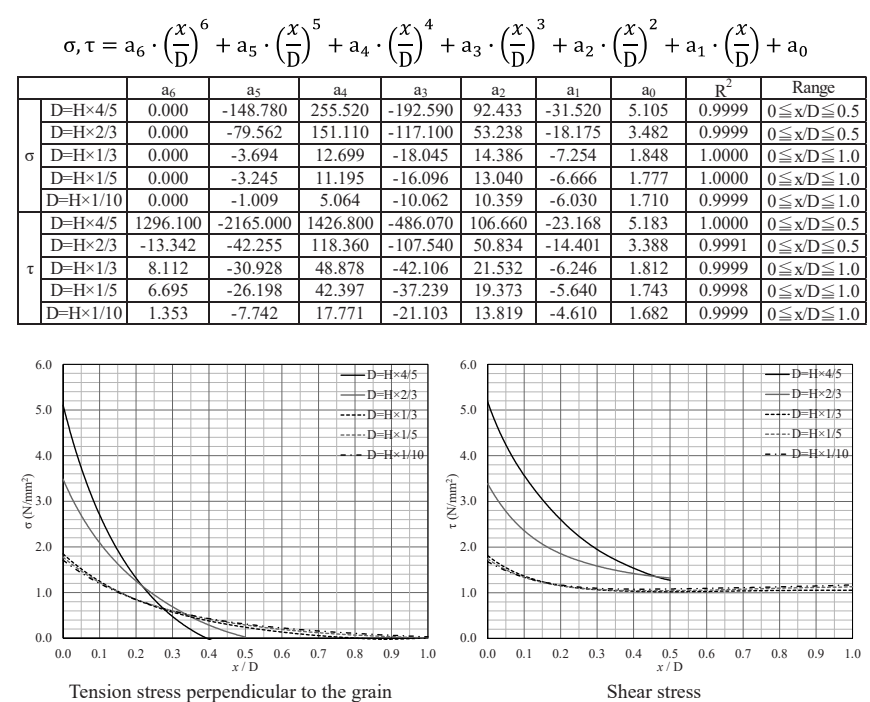

Fig.18 Fitted curve of stress at split fracture location

$$
\begin{aligned}
\bar{\sigma}, \bar{\tau} & =\frac{a_{6}}{7} \cdot\left(\frac{a_{m s}}{D}\right)^{6}+\frac{a_{5}}{6} \cdot\left(\frac{a_{m s}}{D}\right)^{5}+\frac{a_{4}}{5} \cdot\left(\frac{a_{m s}}{D}\right)^{4} \\
& +\frac{a_{3}}{4} \cdot\left(\frac{a_{m s}}{D}\right)^{3}+\frac{a_{2}}{3} \cdot\left(\frac{a_{m s}}{D}\right)^{2}+\frac{a_{1}}{2} \cdot\left(\frac{a_{m s}}{D}\right)+a_{0}
\end{aligned}
$$

\section{3 平均応力による割裂耐力の推定方法と検証}

文献 13)の平均応力による検定式を式(2)、 $\mathrm{a}_{\mathrm{ms}}$ の算定式を式(3)に 示す。式(3)は横引張のみ作用したときのものであり横引張とせん断 が複合で作用する場合は煩雑な式となる。元/秥がきくなるほど $\mathrm{a}_{\mathrm{ms}}$ の值も大きくなっていくが、示/勈 2 までであれば式(3)とほぼ同じ 值であり、4 を超えたあたりから急激に $\mathrm{a}_{\mathrm{ms}}$ が大きくなることが文 献 13)に示されている。ここでは、 $/ \bar{\sigma} は 2$ 以下であるので、簡易な 式(3)で $\mathrm{a}_{\mathrm{ms}}$ を求めることにした。 $\mathrm{F}_{\mathrm{t} 90}, \mathrm{G}_{\mathrm{Ic}}$ は Table2 の值、 $\mathrm{E}_{\mathrm{x}}, \mathrm{E}_{\mathrm{y}}$, $\mathrm{G}_{\mathrm{xy}}$ ， $\mathrm{v}_{\mathrm{xy}}$ は Fig.13の L80 の值を用いて $\mathrm{a}_{\mathrm{ms}}$ を求めると、オウシュウ アカマツでは $33.5 \mathrm{~mm}$ 、カラマツでは $29.6 \mathrm{~mm}$ となる。

$\left(\bar{\sigma} / \mathrm{F}_{\mathrm{t} 90}\right)^{2}+\left(\bar{\tau} / \mathrm{F}_{\mathrm{s}}\right)^{2} \leqq 1.0$

(2)

$$
\mathrm{a}_{\mathrm{ms}}=\frac{2}{\pi} \frac{\mathrm{E}_{\mathrm{I}} \cdot \mathrm{G}_{\mathrm{Ic}}}{\mathrm{F}_{\mathrm{t} 90}{ }^{2}}
$$

ここで $\bar{\sigma}:$ 平均横引張応力度 $\bar{\tau}$ : 平均せん断応力度 $\mathrm{a}_{\mathrm{ms}}$ ：潜在的な破壞領域の一定長さ

$$
E_{I}=\sqrt{\frac{2 \cdot E_{x} \cdot E_{y}}{\sqrt{\frac{E_{x}}{E_{y}}}+\frac{E_{x}}{2 \cdot G_{x y}}-v_{x y}}}
$$

式(1),(2),(3)で有孔梁の割裂耐力を推定すると、孔径が小さい場合 には割裂耐力を高めに推定してしまうので、この点の補正方法を考 える。亀裂のないコンクリートの曲げ性能について文献 16)で詳し くまとめられており、Fig.19 のように H が非常に大きいときの曲 げ強さ $\sigma_{\mathrm{b}(\mathrm{D}=\infty)}$ と $\mathrm{H}$ が小さいときの曲げ強さ $\sigma_{\mathrm{b}}$ との関係は、最大荷 重時の亀裂長さを $\mathrm{H}_{\mathrm{b}} / 2$ として(a)となることが理論的に導かれてい る。 $\mathrm{H}_{\mathrm{b}} / 2$ は材料によって異なり、 $\mathrm{H}$ の值にかかわらず一定の值であ る。(b)は長さ $\mathrm{H}_{\mathrm{b}}$ の部分の平均応力を求める式であり、 $\mathrm{H}$ が $\mathrm{H}_{\mathrm{b}}$ に対 して非常に大きくなると(a)と(b)はほぼ同じ值となる。(a)の r は 1 2 の定数であり、文献 16)ではコンクリートの場合 1.47 が最適であ るとされている。木材の横引張もコンクリートと同様と仮定して $\mathrm{r}=1.47$ が最適であるとすると、今回の実験仕様で最終的な割裂耐力 を $\mathrm{r}=1$ と $\mathrm{r}=1.47$ で求めた場合に $0 \sim 3 \%$ 程度の差しかなかったので、 式の簡便化を考えてここでは $\mathrm{r}=1$ であると仮定する。 $\mathrm{H}$ が小さくて も対応可能な平均応力を求めるための一定長さを $\mathrm{am}_{\mathrm{m}}{ }^{\prime}$ は、(a)におい て $\mathrm{r}=1 、 \mathrm{H}_{\mathrm{b}}=\mathrm{a}_{\mathrm{ms}} 、(\mathrm{~b})$ において $\mathrm{H}_{\mathrm{b}}=\mathrm{a}_{\mathrm{ms}}$ 、(a)=(b) とすると式(4)で表す ことができる。

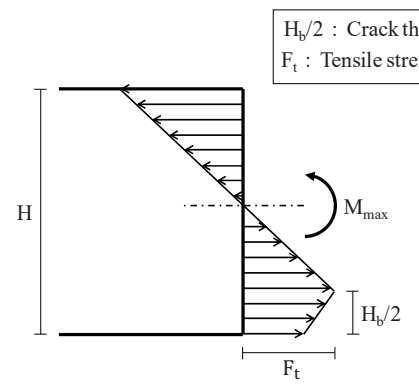

(a) $\sigma_{\mathrm{b}(\mathrm{H}=\infty)}=\sigma_{\mathrm{b}} \cdot \frac{1}{\left(1+\frac{\mathrm{r} \cdot \mathrm{H}_{\mathrm{b}}}{\mathrm{H}}\right)^{1 / \mathrm{r}}}$

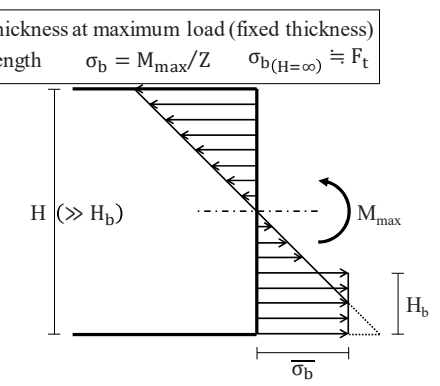

(b) $\sigma_{\mathrm{b}(\mathrm{H}=\infty)}=\overline{\sigma_{\mathrm{b}}}=\sigma_{\mathrm{b}} \cdot\left(1-\frac{\mathrm{H}_{\mathrm{b}}}{\mathrm{H}}\right)$
Fig.19 Stress redistribution of distributed cracking and its approximations

$$
\mathrm{a}_{\mathrm{ms}}{ }^{\prime}=\frac{\mathrm{a}_{\mathrm{ms}}}{1+\frac{\mathrm{a}_{\mathrm{ms}}}{\mathrm{H}}}
$$

有孔梁の場合は横引張の応力度分布が直線ではないので、Fig.20 のように $\sigma_{\max }$ と $\sigma_{\max } / 4$ を結んだ直線として応力分布を考え、 $\sigma=0$ のときの值の 2 倍を式(4)の $\mathrm{H}$ であるとして式(5)に置換する。実験 仕様の有孔梁では、式(5)で $\mathrm{a}_{\mathrm{ms}}$ を補正することで孔径が小さい場合 にも対応できるようになる。

$$
\mathrm{a}_{\mathrm{ms}}{ }^{\prime}=\frac{\mathrm{a}_{\mathrm{ms}}}{1+\frac{\mathrm{a}_{\mathrm{ms}}}{\alpha \cdot \mathrm{D}}}
$$


$a: D=H \times 4 / 5$ の場合 0.55

$\mathrm{D}=\mathrm{H} \times 2 / 3$ の場合 0.7

$\mathrm{D}=\mathrm{H} \times 1 / 3$ 以下の場合 1.0

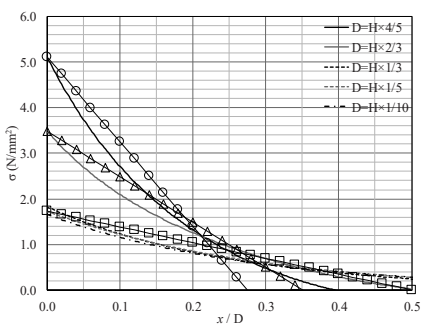

Fig.20 Linear approximation of tension stress perpendicular to grain

次に、寸法効果について考える。Fig.3 の耐力評価法では応力範囲 を仮定することで寸法効果を考慮しているが、ここでは繊維方向と 繊維直交方向の寸法効果をそれぞれ別に設定する。繊維方向の寸法 効果に関しては、Fig.10の実験結果からもわかるように、潜在的な 破壊領域の一定長さの平均応力によって割裂破壊時の応力を求める ことが寸法効果を考慮していることになる。繊維直交方向の寸法効 果に関しては、割裂破壊すると考えられる大きさの応力が作用して いる繊維直交方向長さを考え、ワイブル最弱リンク理論による補正 係数として寸法効果を考慮する。Fig.16 の横引張応力度分布の $\theta=0^{\circ}$ 〜 $90^{\circ}$ の範囲で最大応力度の $80 \%$ 以上が作用している区間はおお よそ $\theta=30^{\circ} \sim 60^{\circ}$ 、最大応力度の $70 \%$ 以上が作用している区間はお およそ $\theta=27^{\circ} \sim 63^{\circ}$ であり、䋊維直交方向の長さにすると $0.18 \mathrm{D}$ 、 $0.23 \mathrm{D}$ となる。よって、最大応力度の $70 \%$ ～ $80 \%$ 以上の部分で破壊 すると仮定し、繊維直交方向の割裂破壊する範囲は Fig.21 に示すよ うに $0.2 \mathrm{D}$ とする。木材は未成熟材の部分の強度が弱く、集成材で はラミナが芯持ちだと芯の部分でラミナが芯去りだと木裏側が弱く なることを考えると、ラミナの厚さである $30 \mathrm{~mm}$ 毎に強度が弱い部 分が存在するので、基準とする長さを $30 \mathrm{~mm}$ とする。係数 $\mathrm{k}$ は文献 17)の半径方向の值として $\mathrm{k}=0.14$ とする。せん断に関しては、文献 18)の曲げ試験から求めたもので $\mathrm{k}=0.18$ 、文献 17)のねじり試験か ら求めたもので $\mathrm{k}=0.09 \sim 0.10$ が得られているが、Fig.21 の 0.2D の ような範囲で作用する応力に対するものに関してはわからない。そ こで、せん断よりも横引張の方が割裂破壊に寄与する割合が非常に 大きいことを考慮し、ここでは横引張と同じ低減であると仮定する。 以上のことから、式(2)を寸法効果による低減を考慮した形にすると 式(6)となる。

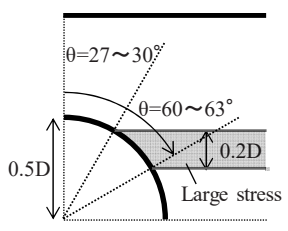

Fig.21 Large stress area

$$
\begin{aligned}
& \sqrt{\left(\bar{\sigma} / \mathrm{F}_{\mathrm{t} 90}\right)^{2}+\left(\bar{\tau} / \mathrm{F}_{\mathrm{s}}\right)^{2}} /\left(\frac{30}{\min (0.2 \mathrm{D}, 30)}\right)^{\mathrm{k}} \leqq 1.0 \\
& \text { ここで } \mathrm{k}=0.14
\end{aligned}
$$

Table2 の平均值を用いて平均応力により曲げせん断実験の割裂 耐力を求めた。実験值と文献 13)で提案されている平均応力による 計算值 (式(1),(2),(3))、 $\mathrm{ams}_{\mathrm{ms}}$ の補正を考慮した計算值 (式(1),(3),(5)) 及び、 $\mathrm{a}_{\mathrm{ms}}$ の補正と繊維直交方向の寸法効果を考慮した計算值（式 (1),(3),(5),(6)) の比較を Fig.22 に示す。平均応力による計算値では、 孔が大きい場合は精度良く推定しているが、孔が小さい場合には初 期クラック荷重を高めに推定する結果となった。しかし、式(5)で $\mathrm{ams}$ の補正を考慮した場合には、孔が小さい場合の初期クラック荷重を 精度良く推定できることが確認できた。また、梁せいが非常に大き い試験体はオウシュウアカマツの $\mathrm{D}=\mathrm{H} \times 1 / 3$ しかないが、式(6)で䋊 維直交方向の寸法効果を考慮した場合には梁せいが非常に大きい場 合の初期クラック荷重を精度良く推定できることが確認できた。繊
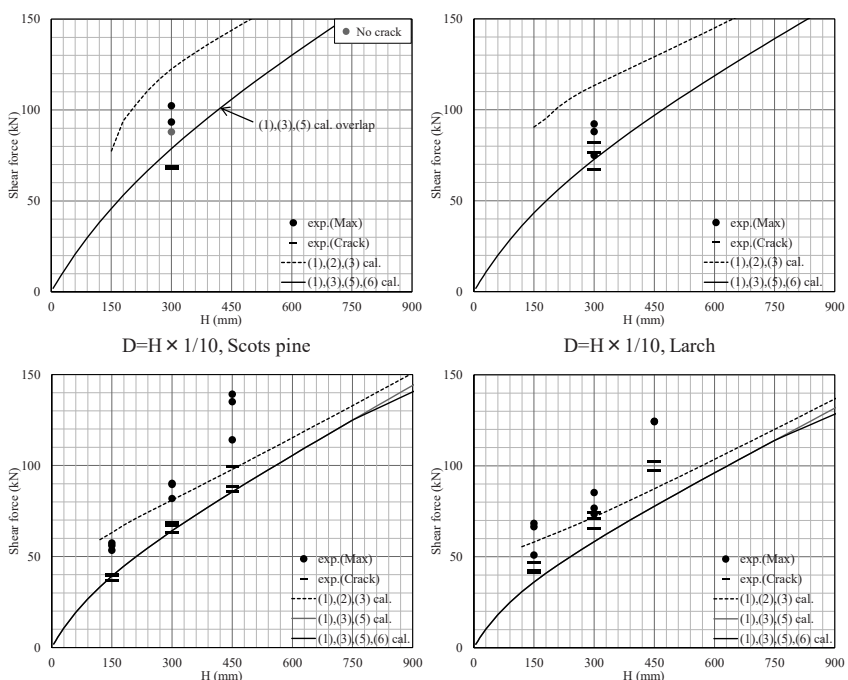

$\mathrm{D}=\mathrm{H} \times 1 / 5$, Scots pine

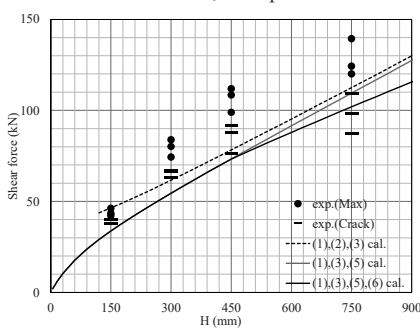

$\mathrm{D}=\mathrm{H} \times 1 / 5$, Larch

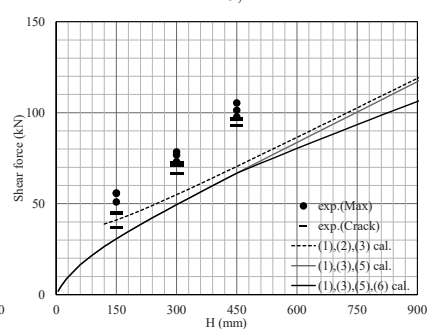

$\mathrm{D}=\mathrm{H} \times 1 / 3$, Scots pine

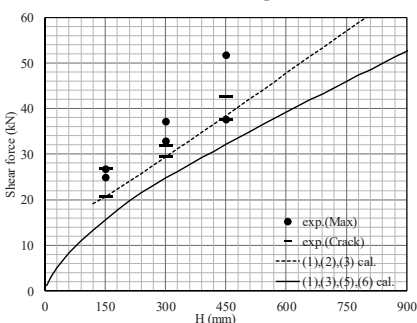

$\mathrm{D}=\mathrm{H} \times 2 / 3$, Scots pine

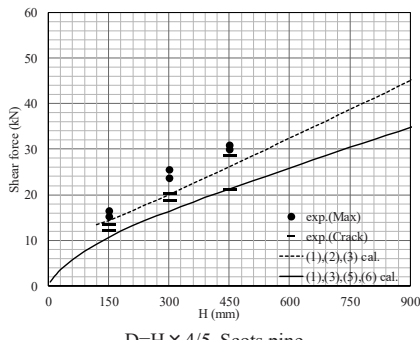

$\mathrm{D}=\mathrm{H} \times 4 / 5$, Scots pine

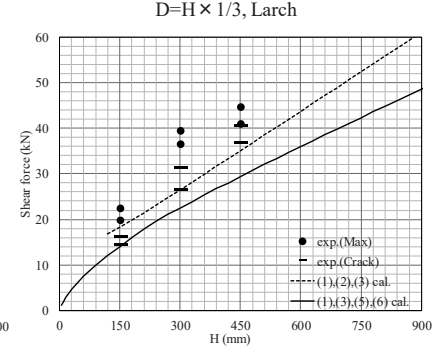

$\mathrm{D}=\mathrm{H} \times 2 / 3$, Larch

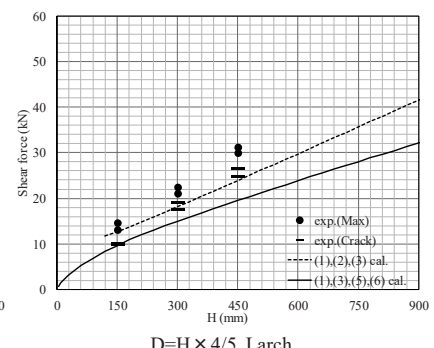

Fig.22 Experimental and calculated values 
維直交方向の寸法効果を考慮しないと計算值は梁せいに概ね比例す ることになるため、梁せいが大きくても孔径が小さい場合にはあま り問題ないが、梁せいが大きくて孔径も大きい場合には、繊維直交 方向の寸法効果を考慮する必要がある。

\section{6. まとめ}

梁せいに対して $1 / 15 \sim 4 / 5$ の孔径を設けた対称異等級構成集成材 の曲げせん断試験を行い、割裂耐力の検討を行った結果、以下の知 見を得た。

(1)対称異等級構成集成材の有孔梁に国内外で提案されている耐力算 定方法をそのまま適用することは難しく、何らかの調整係数が必 要であることがわかった。

(2)潜在的な破壊領域の一定長さ $\mathrm{a}_{\mathrm{ms}}$ の平均応力を用いて割裂耐力を 推定する方法 11)では、孔が小さい場合や大きい場合に、割裂耐力 を高めに推定することがわかった。

(3)平均応力を用いて割裂耐力を推定する方法に、 $\mathrm{a}_{\mathrm{ms}}$ を補正する式 （5）と寸法効果を考慮した検定式(6)を用いることで、梁せいや孔の 大きさ及び樹種の違いに関わらず初期クラック荷重を精度良く推 定できることを示した。

本研究では、FEM を用いて対称異等級構成集成材の有孔梁の割 裂耐力を推定できる方法を示した。このことから、孔の割裂破壊す る位置の繊維方向に作用する横引張とせん断の応力度分布さえ定式 化すれば、有孔梁の耐力評価法を提案できると考えられる。Fig.18 の横引張とせん断の応力度分布では、梁せいに対して $1 / 3$ 以下の孔 径であればほぼ同じような応力度分布を示していることから、ある 程度小さな孔径であれば簡単に定式化できる可能性があることがわ かる。Fig.16では対称異等級構成と同一等級構成で孔周りに作用す る応力度が異なることを示しており、このことに関しても考慮する 必要がある。そこで、対称異等級構成集成材と同一等級構成集成材 の有孔梁の構造性能の違いについての検討や、孔周りに作用寸る横 引張とせん断の応力度分布の定式化と有孔梁の耐力評価法の提案に ついては続報にて示す予定である。

\section{謝辞}

本研究は、JSPS 科研費（18K13867）の助成を受けたものです。 また、実験の一部は（国研）建築研究所研究課題「中高層木造建築 物等の構造設計技術の開発」の一環により実施した。実験及び解析 においては亀崎和海君（元島根大学学生）の協力を得ました。ここ に感謝してお礼申し上げます。

\section{参考文献}

1) Japan $2 \times 4$ Home Builders Association: Design guide of $2 \times 4$ wood frame construction buildings for 2018, Maruzen, 2018. 11 (in Japanese)

日本ツーバイフォー建築協会: 2018 年枠組壁工法建築物設計の手引, 丸 善, 2018. 11

2) Japanese Standards Association: JIS A 3301: 2015 Design standards for wooden construction of school buildings, 2015. 4 (in Japanese) 日本規格協会: JIS A 3301:2015 木造校舎の構造設計標準, 2015. 4

3) H. Danielsson: The strength of glulam beams with holes. A Survey of Tests and Calculation Methods, TVSM-3068, Lund University, 2007

4) H. Danielsson: The strength of glulam beams with holes. A Probabilistic Fracture Mechanics Method and Experimental Tests,
TVSM-3069, Lund University, 2009

5) Masahiro NOGUCHI, Takuro MORI, Kenji MIYAZAWA: A STRENGTH CALCULATION METHOD OF THE TIMBER WITH A CIRCULAR HOLE, Journal of Structural and Construction Engineering (Transactions of AIJ), Vol. 74, No. 640, pp. 1121-1129, 2009. 6 (in Japanese)

野口昌宏, 森拓郎, 宮澤健二: せん断及び曲げモーメント複合応力下の木 質有孔梁の強度算定式, 日本建築学会構造系論文集, 第 74 巻, 第 640 号, pp. 1121-1129, 2009. 6

6) Kazumi HIJIKATA, Hideki IDOTA, Kenta YAMAGISHI: PROPOSAL OF DESIGN STRENGTH FOR GLUE-LAMINATED TIMBER BEAMS WITH A CIRCULAR THROUGH-HOLE, Journal of Structural and Construction Engineering (Transactions of AIJ), Vol. 77, No. 673, pp. 397-406, 2012. 3 (in Japanese) 土方和己，井戸田秀樹，山岸賢多：有孔集成材梁の設計耐力式の提案，日 本建築学会構造系論文集, 第 77 巻, 第 673 号, pp. 397-406, 2012. 3

7) Takahiko SUGINO, Hiro KAWAHARA, Yo OCHIAI, Kenji AOKI, Masahiro INAYAMA: Study on Shear Strength of Glued-Laminated Timber Varying Width and Height of Shear Area, Summaries of Technical Papers of Annual Meeting Architectural Institute of Japan, Structures III, pp. 333-334, 2018. 7 (in Japanese) 杉野貴彦, 河原大, 落合陽, 青木謙治, 稲山正弘：木材のせん断強度にお けるせん断面の幅と高さの影響についての研究，日本建築学会大会学術 講演梗概集，構造 III, pp. 333-334, 2018. 7

8) Hitoshi KUWAMURA: STUDY ON REINFORCEMENT OF SPLITTING TIMBER BY DRIVING WEDGE TEST -Study on steelframed timber structures Part 2-, Journal of Structural and Construction Engineering (Transactions of AIJ), Vol. 73, No. 632, pp. 1779-1786, 2008. 10 (in Japanese)

桑村仁: くさび押込み試験による木材の割裂補強の研究一鉄骨木質構造 の研究 その $2-$, 日本建築学会構造系論文集, 第 73 巻, 第 632 号, pp. 1779-1786, 2008. 10

9) P. J. Gustafsson: Fracture Mechanics Studies of Non-Yielding Materials Like Concrete -Modeling of Tensile Fracture and Appllied Strength Analyses-, TVSM-1007, Lund University, 1985

10) P. J. Gustafsson: Fracture Perpendicular to Grain - Structural Applications, Timber engineering, JOHN WILEY \& SONS LTD, pp. 103-130, 2003

11) H. J. Larsen, P. J. Gustafsson: The fracture energy of wood in tension perpendicular to the grain, CIB W18A, 23-19-2, 1990

12) Takeo YOKOBORI: Strength and fracture of materials (2nd edition), Iwanami Zensho, pp. 301-302, 1974. 10 (in Japanese) 横堀武夫：材料強度学(第 2 版), 岩波全書, pp. 301 302, 1974. 10

13) SIMON AICHER: FRACTURE MECHANICS MODELS. FOR STRENGTH ANALYSIS OF TIMBER. BEAMS WITH A HOLE OR A NOTCH. - A Report of RILEM TC-133, LUND University, 2002

14) Architectural Institute of Japan: Standard for Structural Design of Timber Structures, Maruzen, 2006. 12 (in Japanese) 日本建築学会: 木質構造設計規準 ・同解説, 丸善, 2006. 12

15) Forestry and Forest Products Research Institute: Wood industry handbook, Maruzen, 2004. 3 (in Japanese) 森林総合研究所：木材工業ハンドブック，丸善, 2004. 3

16) Z. P. Bažant: Scaling of Structural Strength, ButterworthHeinemann, 2005. 9

17) Naoyuki Suzuki: Size effect on wood strength, Wood Industry, Vol. 52, No. 6, pp. 278-282, 1997. 6 (in Japanese) 鈴木直之：木材強度の寸法効果, 木材工業, Vol. 52, No. 6, pp. 278-282, 1997. 6

18) R. O. Foschi, J. D. Barrett: Longitudinal shear strength of Douglasfir, Canadian Journal of Civil Engineering, Vol. 3, No. 2, pp. 198-208, 1976 


\section{STUDY ON STRENGTH OF GLUED LAMINATED TIMBER BEAMS WITH ROUND HOLES}

Estimation of splitting strength of glued laminated timber composed of heterogeneous grade by finite element analysis

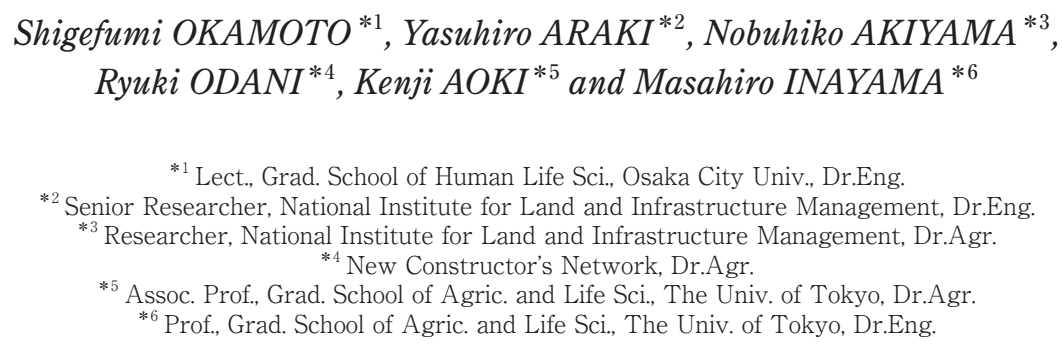

To economically design a building, the beams used may contain holes for placing piping. For steel structures and reinforced concrete structures, methods for evaluating the strength of beams with round holes have been established. However, for timber structures in Japan, a method for evaluating the strengths of beams with round holes has not yet been established.

Several strength evaluation methods have been proposed for the standards of overseas structural design in Japanese research papers. These methods calculate the beam strengths when a hole is split by a tensile force that is perpendicular to the grain. It is possible to determine the strengths of beams with round holes using the proposed strength evaluation method. However, the proposed strength evaluation method has only been verified for homogeneous timber and it is not clear whether this method can be applied to glulams that are glued and laminated timbers composed of heterogeneous grade materials and mainly used for beams in Japan.

The purpose of this study is to experimentally verify that the proposed strength evaluation method can be applied to glulams. An additional objective is to verify that the strengths of these glued and laminated timbers can be estimated by finite element analysis (FEA).

Chapter 1 introduces the proposed strength evaluation method. Chapter 2 introduces the shear bending experiments performed on glulams with round holes. Chapter 3 introduces the element experiments for examining shear and tension strength parallel to the grain, tension strength perpendicular to the grain, and mode I fracture energy. Chapter 4 presents the results of verification that the proposed capacity evaluation method is not applicable to glulams. Chapter 5 proposes a method for estimating the strength of glulams with round holes by FEA and shows the verification results. The results of this study are as follows.

1) It was demonstrated that the strength evaluation method proposed for glulams cannot be applied as it currently exists.

2) The stress distributions around the round holes were obtained by FEA and the method of estimating the splitting strengths using the mean stresses acting across a potential fracture area shown in Reference 11 was verified. As a result, it was found that the splitting strengths were accurately estimated when the round holes were small or large.

3) By using Equation (5) for correcting ams and Equation (6) for considering the size effect in the mean stress method, it was shown that the splitting strengths can be accurately estimated even when the round holes are small or large. 